Publisher homepage: www.universepg.com, ISSN: 2663-6913 (Online) \& 2663-6905 (Print)

https://doi.org/10.34104/ajpab.021.035041

American Journal of Pure and Applied Biosciences

Journal homepage: www.universepg.com/journal/ajpab

\title{
Potassium Fractions and Rice Yield in Different Agro-ecological Zones of Bangladesh
}

\author{
M.R. Karim ${ }^{1}$, Majharul Islam ${ }^{2 *}$, Md. Saikat Hossain Bhuiyan ${ }^{3}$, Sushan Chowhan ${ }^{4}$, Md. Mahmudul Hassan \\ Arif Sardar ${ }^{5}$, and J. A. Mian ${ }^{6}$
}

${ }^{1}$ Project development unit, Bangladesh Tea Board, Chittagong, Bangladesh; ${ }^{2}$ Soil Science Division, BINA, Mymenshingh, Bangladesh; ${ }^{3}$ Plant Breeding division, BINA, Mymenshingh, Bangladesh; ${ }^{4}$ Adaptive Research and Extension Division, BINA, Mymenshingh, Bangladesh; ${ }^{5}$ A R Malik Seeds Pvt. Ltd, Bangladesh; ${ }^{6}$ Soil Science Department, BAU, Mymenshingh, Bangladesh.

*Correspondence: m.islambau03@gmail.com (Majharul Islam, Scientific Officer, Soil Science Division, Bangladesh Institute of Nuclear Agriculture (BINA), Mymenshingh, Bangladesh.

\begin{abstract}
Response of Potassium $(\mathrm{K})$ is boosted due to the introduction of high-yielding varieties and cropping intensity. So, a pot experiment was done to see the allocation of native and added $\mathrm{K}$ in soils and the response of this on rice. Seven soil samples were collected from seven AEZs. An amount of 1-kilogram soil was taken in each of 28 earthen pots of which 14 pots for cultivation rice and 14 pots for without cultivation as a control. Potassium and other fertilizers applied as follows Fertilizer Recommendation Guide-1012. Two replicate plots were used per treatment. Then the soils were saturated with water so that the soils could be soaked well. The pots were kept in this condition for one day to allow the soils to settle in the pots properly. The rice variety used for the experiment was BRRI dhan28. All forms of $\mathrm{K}$ were found to remarkable decrease due to cultivation. The depleted non-exchangeable $\mathrm{K}$ sum was the largest, this was followed by exchangeable and then, in control plots, water-soluble K. The depleted amount of exchangeable and non-exchangeable $\mathrm{K}$ was almost similar but higher than water-soluble $\mathrm{K}$ in treated pots. A significant variation was found among the yields ranging from 3.77 to $5.48 \mathrm{~g} \mathrm{pot}^{-1}$. The average dry matter yield of treated pots $4.75 \mathrm{~g} \mathrm{pot}^{-1}$ was significantly higher than nontreated pots $3.10 \mathrm{~g} \mathrm{pot}^{-1}$.
\end{abstract}

Keywords: Non-exchangeable K, Exchangeable K, Potassium, Agro-ecological zone, and Yield of rice.

\section{INTRODUCTION:}

In current agriculture to achieve required food production to feed rapidly growing population efficient nutrient management is the most important management strategies. People of Bangladesh cannot understand the importance of Potassium uses in agriculture. Potassium requirement of crops are in general identical to nitrogen. Over extraction of $\mathrm{K}$ from soil because of continuous mismatch between crop demand and

UniversePG I www.universepg.com external supply results in depletion of $\mathrm{K}$ reserve (Rabiul et al., 2020). Balanced application of fertilizers is important for sustainable crop production and maintenance of soil health. It is commonly agreed that plants take up $\mathrm{K}$ from or via soil solution. Of the different forms of soil $\mathrm{K}$, the soluble and exchangeable forms contribute to the pool of readily available $\mathrm{K}$, while the initially non exchangeable $\mathrm{K}$ serves as a reserve source of soil K. Only $1-2 \%$ of the soil $\mathrm{K}$ is generally present as readily available forms in soil. 
The balance between different types of soil $\mathrm{K}$ is disturbed by the removal by plant and/or leaching of $\mathrm{K}$ from the soil solution, and also by $\mathrm{K}$ addition by fertilizers, crop residues and possibly also by irrigation. The balance between soluble $\mathrm{K}$ and exchangeable $\mathrm{K}$ is rapid and is formed in a few minutes, but it is much slower between the exchangeable $\mathrm{K}$ and nonexchangeable $\mathrm{K}$, taking several days to even a few weeks to be established. The state and distribution of potassium in soils are almost entirely regulated by soil mineralogy (Fanning et al., 1989). Exchangeable K is widely used for the soil $\mathrm{K}$ status assessment and prediction of crop $\mathrm{K}$ requirements, while in some countries; the $\mathrm{K}$ saturation index (\%) is used for soil $\mathrm{K}$ status evaluation However, recent research works (Bansal et al., 2002) showed that exchangeable $\mathrm{K}$ alone cannot be used as the basis for evaluating $\mathrm{K}$ availability under intensive cropping (Rahman et al., 2020). It was noted that, under intensive cropping with high yielding varieties, those soils which were considered adequate in exchangeable potassium could not sustain that condition for a long time. This reinforced an earlier observation that the potassium drain rises as cropping becomes more intensive and the occurrence of potassium deficiency is likely to spread more widely in the soils of Nigeria's savanna region.

Researchers (Bansal et al., 2002) and (Kirkman et al., 1994) have shown that there is a continuous but slow transfer of potassium from the primary minerals to the exchangeable and slowly available forms. The release of these non-exchangeable forms of $\mathrm{K}$ occurs when, through crop removal and/or leaching, the amount of the exchangeable $\mathrm{K}$ and solution $\mathrm{K}$ (labile $\mathrm{K}$ ) decreases. The quantity of these non-exchangeable types of potassium (total $\mathrm{K}$, reserved $\mathrm{K}$, mobile $\mathrm{K}$ and residual $\mathrm{K})$ present in the soil has recently been the basis for assessing the status of potassium in the soil. In understanding the conditions regulating their accessibility to growing crops, the distribution of these forms in soils is important. Knowledge and understanding of $\mathrm{K}$ dynamics in soil proves to be the best approach in arriving at fertilizer recommendation for crops. Application of fertilizers based on the availability of nutrients in the soil test and crop response to fertilizer applied to the particular yield target is called a precision farming technique based on soil and fertilizer to achieve the target output of food grain and to minimize environmental degradation. Therefore, the present study was undertaken in order to assess the effect of potassium fertilization on the dynamics of soil potassium in rice cultivation.

\section{MATERIALS AND METHODS:}

A pot experiment was set up in the net house of the Department of Soil Science, Bangladesh Agricultural University, Mymensingh during Boro season and the period was 31 December 2017 to 10 March 2018. Soil samples at depth of 0-15 cm were gathered from seven different places under the Agro-ecological Zones: Old Brahmaputra floodplain, Level Barind Tract, Ganges Tidal foodplain, Old Himalayan Piedmont Plain, North Eastern Barind Tract and Madhupur tract. Weeds and other unwanted materials were removed from these samples. Those were air-dried, ground and sieved through a 10 mesh sieve. All fertilizers applied as follows Fertlizer Recommendation Guide-1012. About 1 kilogram soil was taken in each of 28 earthen pots of which 14 pots for Potassium treated soil and 14 pots for without Potassium treated soil. Per treatment, two replicate plots were used. Polythene papers were placed at the bottom of the pots before taking the soil to close the small holes. Then the soils were saturated with water so that the soils could be soaked well. The pots were kept at this condition for one day to allow the soils to settle in the pots properly. After that, the seedlings were transplanted in pots. The rice variety used for the experiment was BRRI dhan28.

\section{Digestion of soil samples in order to determine $\mathbf{K}$ fractions}

Soil samples at the time of harvesting the crop were taken from each of the pots. After collection, the soils were made free from plant roots and air dried and prepared for analysis. Water soluble potassium was calculated by the process adopted by Jackson in 1: 10 of the soil: water extraction (1973) and were determined by flame-photometer. 5 grams of soil was shaken with $50 \mathrm{ml}$ glass redistilled water for 1 hour and allowed to stand overnight. The content was then centrifuged and filtered through Whatman filter paper No. 42.

Exchangeable potassium in soil was determined with $1 \mathrm{~N} \mathrm{NH}_{4} \mathrm{OAc}(\mathrm{pH} 7.0)$ extract of the soil by using 
flame photometer. A $2.5 \mathrm{~g}$ portion of finely ground soil sample was taken in $250 \mathrm{ml}$ Erlenmeyer flask, $25 \mathrm{ml}$ of $1 \mathrm{~N} \mathrm{HNO}_{3}$ was added to it. It was placed on a sand bath and boiled gently for 10 minutes. After cooling, the liquid portion was poured through filter paper into a $100 \mathrm{ml}$ volumetric flask. The remaining soil was washed with $15 \mathrm{ml}$ portions of $0.1 \mathrm{~N} \mathrm{HNO}_{3}$ for four times. The solution was diluted to volume and mixed thoroughly. Potassium was determined with a flame photometer using appropriate $\mathrm{K}$ standards made in the same $\mathrm{HNO}_{3}$ concentration as in the samples. Nonexchangeable $\mathrm{K}$ was obtained by subtracting the exchangeable $\mathrm{K}$ value from the value of total $\mathrm{K}$ extracted with boiling $1 \mathrm{~N} \mathrm{HNO}_{3}$.

\section{Digestion of plant samples in order to determine $\mathbf{K}$}

The air dried plant samples (straw) were dried in an oven at $65^{\circ} \mathrm{C}$ for about 48 hours. They were ground in a grinding machine and kept in bags of paper. The straw samples were analyzed to determine K. A $0.5 \mathrm{~g}$ sub-sample was transferred to a $100 \mathrm{~mL}$ dry clean narrow tube. A di-acid mixture of $10 \mathrm{ml}$ (HNO3: $\mathrm{HClO} 4$ 2:1 ratio) was added. After leaving for a while, the flask was heated at a temperature slowly raised to $180^{\circ} \mathrm{C}$. Heating was momentarily stopped when the dense white fumes of $\mathrm{HClO}_{4}$ occurred. The contents of the flask were boiled until they became clean and colorless. The concentration of $\mathrm{K}$ in the digest was determined directly by a flame photometer (Yoshida et al., 1976).

\section{Statistical analysis}

The analysis of variance for dry matter yield of the crop was done following the F-test. Mean comparisons of the treatments were made by the Duncan's Multiple Range Test, DMRT (Gomez and Gomez, 1984).

\section{RESULTS AND DISCUSSION:}

Water soluble $\mathbf{K}$ - K content which is immediatly available for plant uptake is considered as water soluble K. The results showed a severe depletion of water soluble $\mathrm{K}$ in non-treated pot in all soils. In initial soils the status was 2.30 to $23.40 \mathrm{mg} \mathrm{kg}^{-1}$ soils which decreased to 1.26 to $5.75 \mathrm{mg} \mathrm{kg}^{-1}$ in post-harvest soils after cropping (Table 1). The highest amount of water soluble K was depleted from OHPP soil followed by BAF and BANF soils. The lowest amount of water soluble K was depleted from MT soil. About 89.04\% of water soluble $\mathrm{K}$ was taken up by the crop from BANF soils. The percent use from NEBT soil was $43.91 \%$. The value of GTF soil was more close to NEBT then BANF, OHPP and BAF soils. The amount and percent use from MT soil was the lowest among the soils under study. An amount of 0.36 to $8.58 \mathrm{mg}$ of added $\mathrm{K}$ was transformed into water soluble $\mathrm{K}$ across the soils (Table 1).

Table 1: Change in water soluble $\mathrm{K}\left(\mathrm{mg} \mathrm{kg}^{-1}\right)$ in non-treated soils and treated soils

\begin{tabular}{|c|c|c|c|c|c|c|c|c|c|c|}
\hline \multirow[b]{2}{*}{ Soils } & \multicolumn{3}{|c|}{$\begin{array}{l}\text { Change in native } K \text { in non- } \\
\text { treated soils }\end{array}$} & \multirow{2}{*}{$\begin{array}{c}\% \\
\text { used }\end{array}$} & \multicolumn{5}{|c|}{ Change in K status in K treated soils } & \multirow{2}{*}{$\begin{array}{c}\text { Use } \\
\text { efficiency of } \\
\text { added } \mathrm{K} \\
(\%)\end{array}$} \\
\hline & Initial & $\begin{array}{c}\text { Post- } \\
\text { harvest }\end{array}$ & $\begin{array}{l}\text { Depleted } \\
\text { amount }\end{array}$ & & Initial & $\begin{array}{c}\text { Amount } \\
\text { trans- } \\
\text { formed }\end{array}$ & $\begin{array}{c}\text { Pre } \\
\text { trans- } \\
\text { planting }\end{array}$ & $\begin{array}{c}\text { Post- } \\
\text { harvest }\end{array}$ & $\begin{array}{c}\text { Depleted } \\
\text { amount }\end{array}$ & \\
\hline BAF & 15.50 & 5.16 & 10.34 & $33.29 \mathrm{~d}$ & 15.50 & 3.51 & 19.01 & 2.90 & 16.11 & $458.97 \mathrm{~b}$ \\
\hline BANF & 11.50 & 1.26 & 10.24 & $89.04 a$ & 15.50 & 1.17 & 12.67 & 2.12 & 10.95 & $935.89 \mathrm{a}$ \\
\hline LBT & 6.63 & 5.02 & 1.61 & $24.28 \mathrm{e}$ & 66.30 & 5.85 & 12.48 & 4.16 & 8.32 & $142.22 \mathrm{e}$ \\
\hline GTF & 5.05 & 3.20 & 1.85 & $36.63 d$ & 50.50 & 3.90 & 8.95 & 3.27 & 5.68 & $145.84 \mathrm{e}$ \\
\hline OHPP & 23.40 & 6.75 & 16.65 & $71.15 b$ & 23.40 & 10.53 & 33.93 & 15.68 & 18.25 & $173.31 \mathrm{~d}$ \\
\hline NEBT & 2.30 & 1.29 & 1.01 & $43.91 \mathrm{c}$ & 23.04 & 7.80 & 9.80 & 8.84 & 0.96 & $120.30 \mathrm{f}$ \\
\hline MT & 5.85 & 5.20 & 6.45 & $11.02 \mathrm{f}$ & 58.50 & 1.95 & 7.8 & 3.32 & 6.48 & $332.38 \mathrm{c}$ \\
\hline
\end{tabular}

*Same letters indicate that they are not significantly different at 5\% level of DMRT

**(BAF=Brahmaputra Alluvial Flooded, BANF=Brahmaputra Alluvial Flooded, LBT=Level Barind Tract, GTF=Ganges Tidal Floodplain, OHPP=Old Himalayan Piedmont plain, NEBT= North Eastern Barind Tract and MT= Madhupur Tract). 
As a consequence of which the status of water soluble $\mathrm{K}$ in treated pots were 3.10 to $31.98 \mathrm{mg} \mathrm{kg}^{-1}$ soils before transplantation. Like the non-treated pots, a severe depletion of water soluble $\mathrm{K}$ was also found in post-harvest soils. This showed that the amount of water soluble $\mathrm{K}$ absorbed by plants was much higher than the amount added ( 0.36 to $8.58 \mathrm{mg} \mathrm{kg}-1)$. The largest amount of water soluble $\mathrm{K}$ was taken up from the OHPP soil followed BAF and BANF soil. The percent use efficiency of added $\mathrm{K}$ also showed wide variation across the soils. Majumdar et al. (2002) find similar result that means water soluble $\mathrm{K}$ increased significantly with increasing dose of added $\mathrm{K}$.

Exchangeable $\mathbf{K}$ - Exchangeable $\mathrm{k}$ is the leading form of available $\mathrm{k}$ for plant and have significant relation- ship with non exchangeable and water soluable k. It is also consider as key reservoir of immmediat plant available $\mathrm{k}$. The exchangeable $\mathrm{K}$ of non-treated pot of all soils also decreased over the initial status but it was not as remarkable as was in case of water soluble $\mathrm{K}$. The highest depletion was in LBT soil. The change in exchangeable $\mathrm{K}$ due to crop uptake from OHPP and NEBT soils were almost similar and remarkably higher than other soils except LBT.

The depletion of exchangeable $\mathrm{K}$ in BAF, BANF and GTF soils were 13.56, 14.15 and $14.05 \mathrm{mg} \mathrm{kg}^{-1}$ respectively. The changed amount of MT soil was 9.05 $\mathrm{mg} \mathrm{kg}{ }^{-1}$ which was the lowest amount of exchangeable $\mathrm{K}$ taken up from MT soil. The highest percent use of exchangeable $\mathrm{K}$ was also found in OHPP soil.

Table 2: Change in exchangeable K (mg kg-1) in non-treated and treated soils

\begin{tabular}{|c|c|c|c|c|c|c|c|c|c|c|}
\hline \multirow[t]{2}{*}{ Soils } & \multicolumn{3}{|c|}{$\begin{array}{c}\text { Change in native } K \text { in } \\
\text { control soils (non treated } \\
\text { soil) }\end{array}$} & \multirow[t]{2}{*}{$\%$ use } & \multicolumn{5}{|c|}{ Change in K status in K treated Soils } & \multirow{2}{*}{$\begin{array}{c}\begin{array}{c}\text { Use } \\
\text { efficiency } \\
\text { of added }\end{array} \\
\mathbf{K}(\%)\end{array}$} \\
\hline & Initial & $\begin{array}{c}\text { Post- } \\
\text { harvest }\end{array}$ & $\begin{array}{c}\text { Depleted } \\
\text { amount }\end{array}$ & & Initial & $\begin{array}{c}\text { Amount } \\
\text { transformed }\end{array}$ & $\begin{array}{c}\text { Pre trans- } \\
\text { planting }\end{array}$ & $\begin{array}{c}\text { Post- } \\
\text { harvest }\end{array}$ & $\begin{array}{c}\text { Depleted } \\
\text { amount }\end{array}$ & \\
\hline BAF & 46.80 & 33.24 & 13.56 & $28.97 d$ & 46.8 & 5.85 & 52.65 & 25.07 & 27.58 & $471.45 \mathrm{ab}$ \\
\hline BANF & 27.30 & 13.15 & 14.15 & $51.83 \mathrm{c}$ & 27.3 & 4.31 & 31.61 & 15.67 & 15.94 & $369.83 b c$ \\
\hline LBT & 163.80 & 140.04 & 23.76 & 14.50de & 163.8 & 5.26 & 169.06 & 139.04 & 30.02 & $570.72 \mathrm{a}$ \\
\hline GTF & 132.60 & 118.55 & 14.05 & $10.60 \mathrm{e}$ & 132.6 & 9.75 & 142.35 & 125.98 & 16.37 & $167.89 \mathrm{e}$ \\
\hline OHPP & \begin{tabular}{|l|}
27.30 \\
\end{tabular} & 7.28 & 20.02 & $73.33 a$ & 27.3 & 7.36 & 34.66 & 10.56 & 24.10 & $327.44 \mathrm{c}$ \\
\hline NEBT & 31.20 & 11.27 & 19.93 & $63.87 b$ & 31.2 & 12.28 & 43.48 & 7.02 & 36.46 & $296.90 d$ \\
\hline MT & 58.50 & 49.45 & 9.05 & 15.47de & 58.5 & 6.43 & 64.93 & 38.08 & 26.85 & $417.57 b$ \\
\hline
\end{tabular}

*Same letters indicate that they are not significantly different at $5 \%$ level of DMRT

**(BAF=Brahmaputra Alluvial Flooded, BANF=Brahmaputra Alluvial Flooded, LBT=Level Barind Tract, GTF=Ganges Tidal Floodplain, OHPP=Old Himalayan Piedmont plain, NEBT $=$ North Eastern Barind Tract and MT= Madhupur Tract).

An amount of 4.31 to $12.28 \mathrm{mg}$ of added $\mathrm{K}$ was transformed into exchangeable form across the soils (Table 2). As a result of which the exchangeable $\mathrm{K}$ in treated pots were 31.61 to $169.06 \mathrm{mg} \mathrm{kg}^{-1}$ soil before transplantation. It decreased to 7.02 to $139.04 \mathrm{mg} \mathrm{kg}^{-1}$ in post-harvest soils. This showed a depletion of exchangeable $\mathrm{K}$ due to cropping in treated soils. The highest and the lowest values in post-harvest soils were in LBT and NEBT soils respectively but the used amount was the highest in NEBT soil followed by LBT and BAF soils. However, the percent use efficiency of added $\mathrm{K}$ was highest in LBT soil followed by BAF soil and then MT soil although the

UniversePG I www.universepg.com used amount was higher in NEBT soil. Exchangeable $\mathrm{K}$ increased significantly with increasing dose of $\mathrm{k}$ input, it is also demonstrated by other studies like Amoakwah and Frimpong, (2013), Majumder et al. (2002).

Non-exchangeable $\mathbf{K}$ - In soli non exchangeable $\mathrm{K}$ was considering as reserves from of $\mathrm{K}$. This form of $\mathrm{K}$ is available for plant slowly. Meaningful amount of plant needs potassium are supplied from this fraction of soil K. For incessant crop cultivation when exchangeable $\mathrm{K}$ attains a certain minimal level then non exchangeable $\mathrm{K}$ contribute synonymous role for $\mathrm{K}$ supply. Non exchangeable from of $\mathrm{K}$ is mainly used by 
the crops that have well branched root systime. But contribution of this form of $\mathrm{K}$ is decreased with increased in the level of applied K. Like water soluble and exchange-able $\mathrm{K}$, the non-exchangeable $\mathrm{K}$ also showed depletion in non-treated pots of all soil over the initial status. The changed amount in nonexchangeable $\mathrm{K}$ due to crop uptake from BANF and NEBT soils were almost similar and remarkably higher than the other soils. The highest percent use of non- exchangeable $\mathrm{K}$ was found in MT soil followed by NEBT soil and then BANF soil. The lowest percent use of non-exchangeable $\mathrm{K}$ was found in $\mathrm{BAF}$ soil $(1.03 \%)$. The percent use from the GTF and OHPP soils were almost similar but lower than MT, NEBT and BANF soils but higher than BAF and LBT soil. An amount of 15.60 to $40.35 \mathrm{mg}$ of added $\mathrm{K}$ was transformed into non-exchangeable form across the soils (Table 3).

Table 3: Change in non- exchangeable $\mathrm{K}\left(\mathrm{mg} \mathrm{kg}^{-1}\right)$ in non-treated and treated soils

\begin{tabular}{|c|c|c|c|c|c|c|c|c|c|c|}
\hline \multirow[t]{2}{*}{ Soils } & \multicolumn{3}{|c|}{$\begin{array}{c}\text { Change in native } K \text { in } \\
\text { control soils } \\
\text { (non treated soil) }\end{array}$} & \multirow{2}{*}{$\begin{array}{c}\% \\
\text { use }\end{array}$} & \multicolumn{5}{|c|}{ Change in $\mathrm{K}$ status in $\mathrm{K}$ treated Soils } & \multirow{2}{*}{$\begin{array}{c}\text { Use } \\
\text { efficiency } \\
\text { of added } \\
\mathbf{K}(\%)\end{array}$} \\
\hline & Initial & $\begin{array}{c}\text { Post- } \\
\text { harvest }\end{array}$ & $\begin{array}{c}\text { Depleted } \\
\text { amount }\end{array}$ & & Initial & $\begin{array}{c}\text { Amount } \\
\text { trans- } \\
\text { formed }\end{array}$ & $\begin{array}{c}\text { Pre trans- } \\
\text { planting }\end{array}$ & $\begin{array}{c}\text { Post- } \\
\text { harvest }\end{array}$ & $\begin{array}{c}\text { Depleted } \\
\text { amount }\end{array}$ & \\
\hline BAF & 877.50 & 868.40 & 9.10 & $1.03 \mathrm{~d}$ & 877.50 & 39.00 & 916.50 & 885.24 & 30.70 & $78.71 \mathrm{bc}$ \\
\hline BANF & 799.50 & 783.30 & 18.20 & $2.27 \mathrm{c}$ & 799.50 & 40.35 & 839.85 & 805.12 & 34.73 & $86.07 \mathrm{ab}$ \\
\hline LBT & 768.03 & 760.25 & 8.78 & $1.14 \mathrm{~cd}$ & 768.03 & 31.47 & 799.50 & 773.70 & 25.80 & $81.98 \mathrm{~b}$ \\
\hline GTF & 666.90 & 658.25 & 11.65 & $1.74 \mathrm{~cd}$ & 666.90 & 35.10 & 702.00 & 682.90 & 19.10 & $54.41 \mathrm{bc}$ \\
\hline OHPP & 413.40 & 408.92 & 7.48 & $1.89 \mathrm{~cd}$ & 413.40 & 15.60 & 429.00 & 407.20 & 21.80 & $139.14 \mathrm{a}$ \\
\hline NEBT & 440.7 & 424.25 & 18.45 & $4.18 \mathrm{~b}$ & 440.70 & 31.20 & 471.90 & 456.57 & 15.10 & $48.39 \mathrm{c}$ \\
\hline MT & 234.00 & 221.55 & 14.45 & $6.17 \mathrm{a}$ & 234.00 & 39.00 & 273.00 & 251.10 & 21.90 & $56.15 b c$ \\
\hline
\end{tabular}

*Same letters indicate that they are not significantly different at $5 \%$ level of DMRT.

**(BAF=Brahmaputra Alluvial Flooded, BANF=Brahmaputra Alluvial Flooded, LBT=Level Barind Tract, GTF=Ganges Tidal Floodplain, OHPP=Old Himalayan Piedmont plain, NEBT= North Eastern Barind Tract and MT= Madhupur Tract).

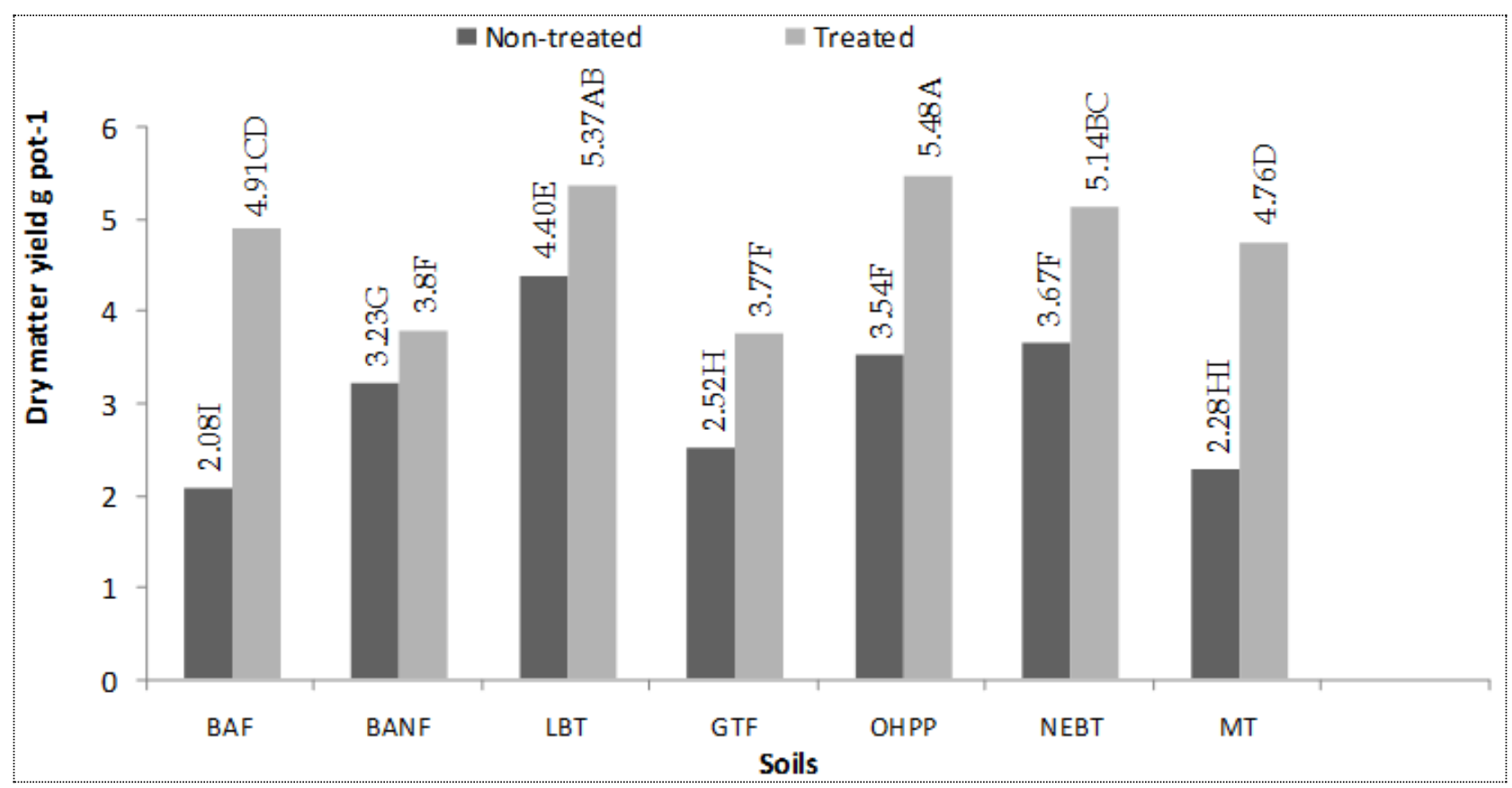

Fig 1: Interaction (soil type \& treatments) effects on dry matter yield of rice plants. 
As a result of which the exchangeable $\mathrm{K}$ in treated pots were 273.00 to $916.50 \mathrm{mg} \mathrm{kg}^{-1}$ soil before transplantation. As a consequence of plant uptake, it decreased to 251.10 to $885.24 \mathrm{mg} \mathrm{kg}^{-1}$ in post-harvest soils. In $\mathrm{K}$ treated pots, a depletion of non-exchangeable $\mathrm{K}$ from 15.10 to $34.73 \mathrm{mg} \mathrm{kg}^{-1}$ was obtained due to cropping. The percent use efficiency of added $\mathrm{K}$ was the highest in OHPP soil followed by BANF soil and then LBT soil. The lowest use efficiency of added $\mathrm{K}$ was found in NEBT soil (48.39\%) followed by GFT and then MT soils. This experimental finding also similar with the agreements of Sharma and Verma, (2000).

Dry matter Yield - The dry matter yields of BRRI dhan 28 in non-treated pots were varied significantly ranging from 2.08 to $4.04 \mathrm{~g} \mathrm{pot}^{-1}$ in different soils under study (Fig 1).

A remarkable increased amount of dry matter yields were found in treated pots over the non-treated amount. A significant variation was found among the yields ranging from 3.77 to $5.48 \mathrm{~g} \mathrm{pot}^{-1}$. The highest amount was found in OHPP soil $5.48 \mathrm{~g} \mathrm{pot}^{-1}$ which was statistically similar to LBT soil but higher than all other soils. The yield of NEBT soil was next to LBT but they were statistically similar. They were followed by BAF and then MT soils. Lower response of added $\mathrm{K}$ on dry matter yield was found in GTF and BANF soils. The average dry matter yield of treated pots 4.75 $\mathrm{g} \mathrm{pot}^{-1}$ was significantly higher than non-treated pots $3.10 \mathrm{~g} \mathrm{pot}^{-1}$. Dwivedi et al. (2006) found positive effect of $\mathrm{k}$ on rice growth and yield.

\section{CONCLUSION:}

All forms of K were found remarkable decrease due to cultivation. The depleted amount of non-exchangeable $\mathrm{K}$ was the highest, this was followed by exchangeable and then water soluble $\mathrm{K}$ in control plots. The depleted amount of exchangeable and non-exchangeable $\mathrm{K}$ was almost similar but higher than water soluble $\mathrm{K}$ in treated pots. A significant variation was found among the yields ranging from 3.77 to $5.48 \mathrm{~g} \mathrm{pot}^{-1}$. The average dry matter yield of treated pots $4.75 \mathrm{~g} \mathrm{pot}^{-1}$ was significantly higher than non-treated pots $3.10 \mathrm{~g}$ pot $^{-1}$. The highest amount was found in OHPP soil 5.48 g pot $^{-1}$ which was statistically similar to LBT soil but higher than all other soils.

\section{ACKNOWLEDGMENT:}

The authors would like to express their heartfelt appreciation and gratitude to all Banaladesh Agricultural University laboratories and workers for their full cooperation during the entire research work. The authors also acknowledge the performance to the funding of this experiment from Bangladesh Agricultural University, Mymensingh.

\section{CONFLICTS OF INTEREST:}

Authors do not have to report any conflicts of interest.

\section{REFERENCES:}

1) Amoakwah, E. and Frimpong K. A. (2013). Relationships between potassium forms and selected physico-chemical porperties of some Ghanaian soils along a topsequence. Arpon Journal of Engineering and Applied Sciences 8: 7 . http://arpnjournals.com/jeas/research_papers/rp 2013/jeas_0713_914.pdf

2) Bansal, S. K., Rao, C. S., Pasricha, N. S. and Imas, P. (2002). Potassium dynamics in major benchmark soil series of India under long term cropping. WCSS, Thailand, 276: 1-21. https://agris.fao.org/agris-search/search.do?rec ordID $=$ TH2014001164

3) Dwivedi, A. P., Dixit, R. S. and Singh, G. R. (2006). Effect of potassium levels on growth, yield and quality of hybrid rice, Department of Agronomy, Narendra Dev University Agriculture Technology, Uttar Pardesh, India.

4) Fanning, D. S., Keramidas, V. Z. and EIDesoky, M. A. (1989). Micas. In: Minerals in Soil Environment (Dixon, J.B. and Weed, S.B., Eds.). Soil Science Society of America, Madison, Wisconsin, U.S.A. 552-634. https://doi.org/10.2136/sssabookser1.2ed.c12

5) Jackson, M. L., Mokma, D. L., Syers, J. K. and Gibbons, F. R. (1973). Mineralogy and radioisotope retention properties of a chronosequence of soils developed in basalts of Victoria, Australia. Journal of Soil Science. 24: 199-214. https://doi.org/10.1111/j.1365-2389.1973.tb007 $\underline{56 . x}$ 
6) Kirkman, J. H., Basker. A., Surapaneni, A. and MacGregor, A. N. (1994). Potassium in the soils of New Zeland - A review. New Zealand Journal of Agricultural Research. 37: 207227.

7) Majumdar, B., Venkatesh, M. S., Kailash, K. and Patiram, (2002). Effects of levels of potassium and FYM on yield and uptake of nutrients by sweet potato and different forms of $\mathrm{K}$ in an Acid Alfisol of Meghalaya. Journal of Potassium Research, 18: 84-89.

https://www.researchgate.net/publication/236969 $\underline{098}$

8) Rabiul I, Uddin ME, and Alam MF. (2020). Isolation, identification and characterization of Rhizobium species from soil of Cicer arietinum field of Faridpur in Bangladesh,
Intern. J. of Curr. Res., 12(4), 10322-10325. https://doi.org/10.24941/ijcr.38456.04.2020

9) Rahman MM, Kabir $\mathrm{MH}$, and Delwar $\mathrm{M}$ Hossain. (2020). Evaluation of some fungicides against collar rot Disease of soybean. Am. J. Pure Appl. Sci., 2(5), 159-166. https://doi.org/10.34104/ajpab.020.01590166

10) Sharma, R. P. and Verma, T. S. (2000). Effects of long-term Lantana addition on soil potassium fractions, yield and potassium uptake in rice-wheat cropping in acid Alfisols. Journal of Potassium Research, 16: 41-47.

11) Yoshida, S. Forno, D. A., Cock, D. H. and Gomez, K. A. (1976). Laboratory manual for physiological studies of rice. $3^{\text {rd }}$ ed. IRRI, Los Banos, Laguna. http://books.irri.org/9711040352_content.pdf

Citation: Karim MR, Islam M, Bhuiyan MSH, Chowhan S, Sardar MMHA, and Mian JA. (2021). Potassium fractions and rice yield in different agro-ecological zones of Bangladesh. Am. J. Pure Appl. Sci., 3(2), 35-41. https://doi.org/10.34104/ajpab.021.035041 क क 